\title{
Anaerobic co-digestion of acerola (Malphigia emarginata) agro-industry effluent with domestic sewage at mesophilic and thermophilic conditions
}

\section{Co-digestão anaeróbia de efluente da agroindústria da acerola (Malphigia emarginata) com esgoto doméstico em condições mesófilas e termófilas}

\author{
Andreza Carla Lopes André ${ }^{1}$; Eduardo Souza Costa Barros ${ }^{2}$; \\ Paula Tereza de Souza e Silva ${ }^{3}$; Dian Lourençoni ${ }^{4}$; \\ Miriam Cleide Cavalcante de Amorim ${ }^{5}$
}

\begin{abstract}
This study evaluated the effect of temperature on the anaerobic co-digestion of acerola agro-industry effluent $(\mathrm{EAV})$ and domestic sewage (EDT). The assays were performed in triplicates of reactor flasks using treatments with different mixture compositions $\left(\mathrm{T}_{1}=5 \% \mathrm{EDT}+95 \% \mathrm{EAV} ; \mathrm{T}_{2}=20 \% \mathrm{EDT}+80 \% \mathrm{EAV} ; \mathrm{T}_{3}=30 \% \mathrm{EDT}\right.$ $+70 \%$ EAV) and anaerobic sludge as inoculum $\left(5\right.$ g. $\left.\mathrm{L}^{-1}\right)$, at mesophilic $\left(35^{\circ} \mathrm{C}\right)$ and thermophilic $\left(55^{\circ} \mathrm{C}\right)$ temperatures. The analyses of soluble chemical oxygen demand $\left(\mathrm{COD}_{\mathrm{s}}\right)$ and volatile fatty acids (VFA) were performed by determining the removal efficiency of the CODs, the decay rate constant of the COD $\left(\mathrm{K}_{\mathrm{d}}\right)$, and the percentages of anaerobic biodegradability (\%BD) and methanation $(\% \mathrm{M})$. The inoculum biomass of the treatments was observed through scanning electron microscopy (SEM) at the end of the degradation process (12 days). Regardless of the temperature, the anaerobic digestion was considered efficient, with biodegradability above $60 \%$. The mesophilic temperature favored the anaerobic co-digestion for all mixture compositions, presenting more diversified and structured biomass at the end of the assays, as well as higher removal efficiencies of the $\mathrm{COD}_{\mathrm{s}}$ and methanization, especially for $\mathrm{T}_{3}$ at $35{ }^{\circ} \mathrm{C}(63 \%$ and $51 \%$, respectively). Furthermore, the kinetics of the degradation process proved to be more accelerated at mesophilic conditions $\left(\mathrm{K}_{\mathrm{d}} 0.1 \mathrm{~d}^{-1}\right)$ and in the treatments with a higher percentage of sewage $\left(\mathrm{T}_{2 \mathrm{M}}\right.$ and $\left.\mathrm{T}_{3 \mathrm{M}}\right)$.
\end{abstract}

Keywords:Biodegradation. Methanation. Temperature.

\section{Resumo}

Este estudo avaliou o efeito da temperatura na co-digestão anaeróbica de efluente da agroindústria aceroleira (EAV) e esgoto doméstico tratado (EDT). Os ensaios foram realizados em frascos reatores em triplicata utilizando tratamentos com diferentes composições de mistura $\left(\mathrm{T}_{1}=5 \% \mathrm{EDT}+95 \% \mathrm{EAV} ; \mathrm{T}_{2}=20 \% \mathrm{EDT}\right.$ $\left.+80 \% \mathrm{EAV} ; \mathrm{T}_{3}=30 \% \mathrm{EDT}+70 \% \mathrm{EAV}\right)$ e lodo anaeróbico como inóculo $\left(5 \mathrm{~g} . \mathrm{L}^{-1}\right)$, em temperaturas mesófilas $\left(35^{\circ} \mathrm{C}\right)$ e termófilas $\left(55^{\circ} \mathrm{C}\right)$. Foram realizadas análises de demanda química de oxigênio solúvel $\left(\mathrm{DQO}_{\mathrm{s}}\right)$ e ácidos graxos voláteis (AGV) determinando-se a eficiência de remoção de $\mathrm{DQO}$, a taxa de decaimento de DQO $\left(\mathrm{K}_{\mathrm{d}}\right)$, e os percentuais de biodegradabilidade anaeróbica (\%BD) e metanização (\%M). A biomassa do inóculo dos tratamentos foi observada através de microspia eletrônica de varredura (MEV) no final do processo de degradação (12 dias). Independente da temperatura, a digestão anaeróbia foi considerada eficiente, com biodegradabilidade superior a $60 \%$. A temperatura mesófila favoreceu a co-digestão anaeróbia para todas as composições de mistura, apresentando biomassa mais diversificada e estruturada ao final dos ensaios, bem como maiores eficiências de remoção de DQOs e metanização, especialmente para $\mathrm{T}_{3}$ a $35^{\circ} \mathrm{C}$ (63\% e $51 \%$, respectivamente). Além disso, a cinética do processo de degradação revelou-se mais acelerada em condições mesófilas $\left(\mathrm{K}_{\mathrm{d}} 0.1 \mathrm{~d}^{-1}\right)$ e nos tratamentos com maior percentual de esgoto $\left(\mathrm{T}_{2 \mathrm{M}} \mathrm{e} \mathrm{T}_{3 \mathrm{M}}\right)$.

Palavras-chave: Biodegradação. Metanização. Temperatura.

\footnotetext{
${ }^{1}$ Agri. and Environ. Engineering, UNIVASF, Juazeiro, Bahia, Brazil, E-mail: andreza_carlalopes@hotmail.com

${ }^{2}$ Master in Agricultural Engineer, UNIVASF, Juazeiro, Bahia, Brazil. E-mail: barros-eduardo2005@ hotmail.com

${ }^{3}$ Researcher at EMBRAPA semiarid, Petrolina, Pernambuco, Brazil. E-mail: paula.silva@embrapa.br

${ }^{4}$ Prof. Dr., Dept of Agri. and Environ. Engineering, UNIVASF, Juazeiro, Bahia, Brazil. E-mail: dian.lourenconi@ univasf.edu.br

${ }^{5}$ Prof. Dr., Dept of Agri. and Environ. Engineering, UNIVASF, Juazeiro, Bahia, Brazil. E-mail: miriam.cleide@ univasf.edu.br
} 


\section{Introduction}

Given its high perishability, the processing of acerola (Malpighia emarginata D.C.) became an important alternative for the maintenance of the productive chain of this fruit, ensuring its quality and commercialization (MALEGORI et al., 2017). However, during fruit processing, residual waters are generated, which may represent a source of environmental pollution if not subjected to some sort of treatment (BOLZONELLA et al., 2019).

The agroindustry uses ultrafiltration in fruit processing, which consists in the separation by semipermeable membranes, used for the clarification of fruit juices (STOFFEL; MOREIRA, 2013). The fraction that does not permeate the membrane is called retentate or residue of the clarification process, which, due to its composition and amount generated, may constitute an environmental impact (PENHA et al., 2001). It is especially characterized by the high content of organic matter in terms of chemical oxygen demand (COD) and proteins, with lower contents of sugars and salts, conferring it a characteristic of hard biological degradation, or recalcitrant.

In this sense, studies point to anaerobic digestion as an effective process for the treatment of agro-industry effluents (CORREIA; DEL BIANCHI, 2008; PUKASIEWICZ et al., 2017). It use for the biologic treatment of residual waters has revealed to be highly attractive due to the lower operational costs for implantation, savings with aeration, low sludge production, and especially the obtainment of clean energy in the form of methane and value-added by-products, such as volatile fatty acids and bioproducts (DE CLERCQ et al., 2017; ESPOSITO et al., 2012). Review papers have reported excellent results of anaerobic digestion processes in agro-industrial effluents through the co-digestion of different combinations of municipal, industrial, and agricultural residues (HAGOS et al., 2017), although few of them approach the recalcitrant effluents of wastewaters in the fruit farming agroindustry (SHEN et al., 2019). In this particular case, according to the studies performed by Montefusco et al. (2019), the effluent from the ultrafiltration in the acerola processing presents this characteristic. Zhang et al. (2013) affirm that anaerobic digesters that use monodigestion are more susceptible to greater instabilities in the process, presenting undesirable drops in performance (due to imbalanced nutritional profiles), accumulation of volatile fatty acids, and consequent inhibition of methanogenesis.
When employing different effluents, the anaerobic co-digestion can overcome difficulties related to the recalcitrant character of one of the effluents, as well as the deficiencies of mono-digestion (ANDRÉ et al., 2020; SIDDIQUE; WAHID, 2018), since it promotes greater stability of the process, resulting in a more balanced and diversified substrate in terms of nutrients, provides the dilution of eventual toxic compounds present in one of the co-substrates, increases the content of biodegradable compounds, besides promoting the increase of bacterial strains that will take part in the process, and improvement of the methane production rate (ATANDI; RAHMAN, 2012; CHOW et al., 2020; ESPOSITO et al., 2012).

However, it is worth noting that several parameters can affect anaerobic digestion, such as the type of substrate, volumetric organic load, and temperature (AMANI; NOSRATI; SREEKRISHNAN, 2010; XU et al., 2019). Among these, temperature is considered one of the most important parameters in anaerobic digestion, as they affect microbial growth and species selection, because it can influence the process in several ways, affecting from the solubility of substrates to the speed of metabolism of microorganisms (RITMANN; MCCARTY, 2001).

According to Metcalf and Eddy (2003), microorganisms can be classified according to the temperature range in which they develop best into: psychrophiles (12$\left.18^{\circ} \mathrm{C}\right)$, mesophiles $\left(25-40^{\circ} \mathrm{C}\right)$, or thermophiles $\left(55-65^{\circ} \mathrm{C}\right)$. Although anaerobic digestion is commonly performed with an operating temperature within the mesophilic range ( 30 to $35^{\circ} \mathrm{C}$ ), studies suggest that the thermophilic range (50 to $55^{\circ} \mathrm{C}$ ) can potentialize the process, resulting in greater removal efficiency of organic matter (WIJAYA $e t$ al., 2020).

Within this context, and considering that the operational parameters interfere with the biomethanation process and that the domestic sewage, according to Bertolino, Carvalho and Aquino (2008), represents a significant source of organic matter, thus being potentially able to be included as a co-substrate for co-digestion, the present study aimed to evaluate the efficiency of the anaerobic co-digestion of the effluent from green acerola processing and from treated domestic sewage in batch flask reactors with different mixture compositions at mesophilic $\left(35^{\circ} \mathrm{C}\right)$ and thermophilic conditions $\left(55^{\circ} \mathrm{C}\right)$, obtaining the mass balance and the rate of the organic load removal process in terms of chemical oxygen demand and analyzing the biomass morphology of the inoculum. 


\section{Material and methods}

\section{Substrates: collection and characterization}

The anaerobic co-digestion assays were performed by the association of the effluent from the ultrafiltration stage of acerola processing with the treated domestic sewage, originated from the NIAGRO (Nichirei do Brasil Agrícola Ltda, agroindustry located in the Industrial District of Petrolina-PE, Brazil) and from COMPESA (State Sanitation Company of Pernambuco, Petrolina-PE, Brazil), respectively. Individual samples were collected and these stored at $4{ }^{\circ} \mathrm{C}$ until the moment of the analytical characterization and use in the experiment.

The substrates were characterized by the determination of the COD, proteins, carbohydrates, nitrogen, total phosphorus, $\mathrm{pH}$, and VFA, according to the Standard Methods for the Examination of Water and Wastewater (APHA, 2012), as shown in Table 1.

\section{Inoculum}

The anaerobic sludge from a UASB reactor (Upflow Anaerobic Sludge Blanket) was used as inoculum, originated from a sewage treatment plant (ETE) of the State Sanitation Company of Pernambuco (COMPESA), located in Petrolina-PE, Brazil, with specific methanogenic activity of $0.223 \mathrm{~mL} \mathrm{CH}_{4}$. g TVS d $\mathrm{d}^{-1}$. The initial microbial concentration in terms of total volatile solids (TVS) in the mixture was $5 \mathrm{~g}$ TVS.L ${ }^{-1}$ (BERTOLINO; CARVALHO; AQUINO, 2008), with nutritional supplementation according to Florêncio (1994).

Anaerobic Co-digestion Assays: temperatures and mixing ratios

In order to evaluate the effect of temperature on the anaerobic co-digestion process through the association of the above-mentioned effluents, batch assays were conducted in reactor flasks with $0.89 \mathrm{~L}$ of useful volume and $0.22 \mathrm{~L}$ of headspace, as recommended by Holliger et al. (2016).

For the mesophilic and thermophilic conditions, the temperatures of $35^{\circ} \mathrm{C}\left(\mathrm{T}_{\mathrm{M}}\right)$ and $55^{\circ} \mathrm{C}\left(\mathrm{T}_{\mathrm{T}}\right)$ were evaluated, respectively, with all treatments in triplicate plus the blank of each temperature, totaling 20 reactor flasks.

The flasks were placed in a room on a bench and with the aid of a Comfort ${ }^{\circledR}$ PR $1500 \mathrm{~W}$ electric heater, the room temperature was kept at $35^{\circ} \mathrm{C}$. For the thermophilic assays, the reactor flasks were immersed in water within a thermal box equipped with a heating system by means of an immersion heater and a temperature sensor, both connected to an Arduino, which was previously programmed to maintain the temperature at $55{ }^{\circ} \mathrm{C} \pm 0.5{ }^{\circ} \mathrm{C}$. The homogenization of temperature in the thermal box was ensured by means of a submersible filter pump (flow of $350{\mathrm{~L} . \mathrm{h}^{-1}}^{-1}$ ) connected continuously to promote water circulation, avoiding the formation of cold-water pockets, illustrated in Figure 1.

Figure 1 - Scheme of the treatments conducted at $55{ }^{\circ} \mathrm{C}$.

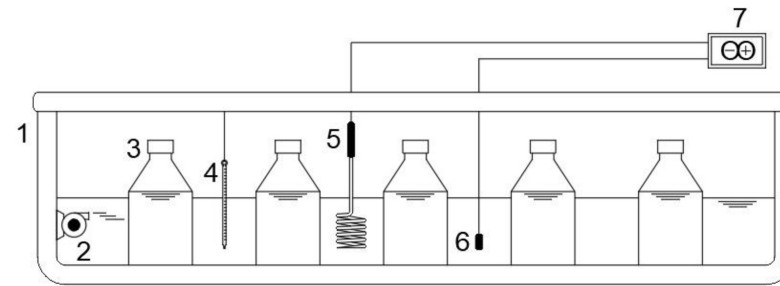

1 - Thermal box

3 - Reactor flasks;

2 - submersible pump;

5 - Immersion heater

4 - Thermometer;

7 - Arduino.

6 - Thermostat;

Source: The authors.

A completely randomized design was adopted, and the co-digestion mixing ratios were defined by adopting a higher percentage of the green acerola processing effluent in relation to the domestic sewage, for the mesophilic and thermophilic conditions, according to Table 2 .

The $\mathrm{pH}$ of all mixtures in the reactor flasks was measured with a Tecnopon ${ }^{\circledR} \mathrm{pH}$ meter, model MPA210, and corrected at the beginning of the assays (day zero) to ensure values close to neutrality using sodium bicarbonate. Afterward, the reactor flasks were isolated from light, closed, and properly sealed to maintain anaerobic conditions.

The assays lasted for $288 \mathrm{~h}$, in which $30 \mathrm{~mL}$ aliquots were removed every $48 \mathrm{~h}$ from the reactor flasks in order to perform the analyses of VFA (APHA, 2012) and $\mathrm{COD}_{\mathrm{S}}$, closed reflux method, as described in APHA (2012).

Evaluation and performance of the process: Mass balance in terms of COD and kinetics of the reaction

For the mass balance, the mass removal efficiency $\left(\mathrm{COD}_{\mathrm{rem}}\right)$ of the $\mathrm{COD}_{\mathrm{S}}$, the COD effectively transformed into methane $\left(\mathrm{COD}_{\mathrm{CH} 4}\right)$ and the COD present in the effluent in the form of volatile fatty acids not converted to methane $\left(\mathrm{COD}_{\mathrm{VFA}}\right)$ were determined. 
Table 1 - Composition of the green acerola processing effluent (EAV) and treated domestic sewage (EDT).

\begin{tabular}{lcccccc}
\hline COD & $\begin{array}{c}\text { Proteins } \\
(\mathbf{m g . L}\end{array}$ & $\begin{array}{c}\text { Carbohydrates }) \\
(\mathbf{m g . L}\end{array}$ & $\begin{array}{c}\text { Total Nitrogen } \\
(\mathbf{m g . L}\end{array}$ & $\begin{array}{c}\text { Total Phosphorus } \\
\left(\mathbf{m g . L}^{-1}\right)\end{array}$ & pH \\
\hline EAV & 79.078 & 52.536 & 54.950 & 230 & 1.402 & 3.2 \\
EDT & 278 & 154 & 0 & 23 & 24.36 & 7.3 \\
\hline
\end{tabular}

EAV: Green acerola processing effluent;

EDT: Treated domestic sewage.

Source: The authors.

Table 2 - Mixing ratios and initial COD.

\begin{tabular}{ccc}
\hline Treatments & Mixing ratio in relation to the useful volume of the reactor & Initial COD $\left(\mathbf{g .} \mathbf{L}^{-1}\right)$ \\
\hline $\mathrm{T}_{1 \mathrm{M}}$ & $5 \%$ of EDT $+95 \%$ of EAV & 40.5 \\
$\mathrm{~T}_{1 \mathrm{~T}}$ & & 44.3 \\
$\mathrm{~T}_{2 \mathrm{M}}$ & $20 \%$ of EDT $+80 \%$ of EAV & 36.0 \\
$\mathrm{~T}_{2 \mathrm{~T}}$ & & 39.2 \\
$\mathrm{~T}_{3 \mathrm{M}}$ & $30 \%$ of EDT $+70 \%$ of EAV & 28.8 \\
$\mathrm{~T}_{3 \mathrm{~T}}$ & & 25.5 \\
\hline
\end{tabular}

EDT: Treated domestic sewage;

EAV: Green acerola processing effluent;

$\mathrm{T}_{1 \mathrm{M}}$ : Treatment 1 at $35^{\circ} \mathrm{C} ; \mathrm{T}_{2 \mathrm{M}}$ : Treatment 2 at $35^{\circ} \mathrm{C} ; \mathrm{T}_{3 \mathrm{M}}$ : Treatment 3 at $35^{\circ} \mathrm{C}$;

$\mathrm{T}_{1 \mathrm{~T}}$ : Treatment 1 at $55^{\circ} \mathrm{C} ; \mathrm{T}_{2 \mathrm{~T}}$ : Treatment 2 at $55^{\circ} \mathrm{C}$; T3T: Treatment 3 at $55^{\circ} \mathrm{C}$.

Source: The authors.

The $\mathrm{COD}_{\mathrm{CH} 4}$ was calculated according to Metcalf and Eddy (2003), in which $\mathrm{COD}_{\mathrm{CH} 4}$ is the COD of thecumulative methane production based on 0.395L CH4. $(\mathrm{g} \mathrm{COD})^{-1}$. The COD ${ }_{\text {VFA }}$ was calculated by the difference between the initial COD mass $\left(\mathrm{COD}_{\text {initial }}\right)$ and the $\mathrm{COD}_{\mathrm{CH} 4}$, assuming as zero the COD for the formation of new cells, due to the degradation period.

The percentage of $\% \mathrm{BD}$ and the $\% \mathrm{M}$ were calculated according to Elbeshbishy and Nakhla (2012), given by equations (1) and (2), respectively

$$
\begin{gathered}
\% B D=\left(\frac{\mathrm{COD}_{\text {initial }}-\mathrm{COD}_{\text {final }}}{\mathrm{COD}_{\text {initial }}}\right) \times 100+ \\
+\left(\frac{\mathrm{COD}_{\mathrm{VFA}}}{\mathrm{COD}_{\text {initial }}}\right) \times 100 \\
\% \mathrm{M}=\left(\frac{\mathrm{COD}_{\mathrm{CH} 4}}{\mathrm{COD}_{\text {initial }}}\right) \times 100
\end{gathered}
$$

The co-digestion kinetics was evaluated using as a parameter the organic load removal rate in terms of COD applied per liter of the reactor $\left(\mathrm{COD}_{\mathrm{Apl}} \mathrm{L}_{\mathrm{R}}^{-1}\right)$, calculating the degradation rate constant $\mathrm{K}_{\mathrm{d}}$ considering that in a batch reactor the rate of change of reagent concentration is proportional to the concentration of this reagent in a given instant, admitting, therefore, a first-order reaction (METCALF; EDDY, 2003; NIKOLAEVA et al. 2009), given by equation (3)

$$
\mathrm{r}=\frac{\mathrm{dS}}{\mathrm{dt}}=-\mathrm{K}_{\mathrm{d}} S
$$

where $\mathrm{r}$ is the reaction speed (g.L $\mathrm{L}^{-1}$ days), $\mathrm{S}$ is the load of the limiting reagent $\mathrm{COD}(\mathrm{g})$, $\mathrm{t}$ is the hydraulic detention time (days), and $\mathrm{K}_{\mathrm{d}}$ is the rate constant for the first-order reaction $\left(\mathrm{d}^{-1}\right)$.

\section{Morphological analysis of inoculum biomass}

At the end of the assays, the microbiota that constitutes the inoculum sludge of the treatments that presented the best methanization efficiencies at each temperature was analyzed by SEM, following the methodology by Araújo et al. (2003), in which $0.5 \mathrm{~mL}$ samples of the inoculum were fixed with phosphate buffer ( $\mathrm{pH} 7.3$ ) containing $25 \%$ glutaraldehyde for $2 \mathrm{~h}$ at $4{ }^{\circ} \mathrm{C}$, dehydrated with ethanol solutions by washing the samples 6 times, at 10-minute intervals, with growing concentrations (45, $70,80,95$, and $100 \%{\mathrm{v} . \mathrm{v}^{-1}}^{-1}$, placed on aluminum stubs with double-sided carbon ribbon, and dried at $30{ }^{\circ} \mathrm{C}$ in a forced-air oven, for $2 \mathrm{~h}$. Afterward, the samples were covered with a $20 \mathrm{~nm}$ thick gold layer, in a Quorum ${ }^{\circledR}$ 
sputter coater, model Q 150R ES, with a $15 \mathrm{~mA}$ current and metallization time of $90 \mathrm{~s}$, with the observations performed in a VEGA3 TESCAN scanning electron microscope.

\section{Statistical Analyses}

The results of COD removal and \%M were subjected to ANOVA, and the means were compared by Tukey's test at $5 \%$ of probability using the SISVAR statistical software (FERREIRA, 2011).

\section{Results and discussion}

\section{Removal efficiency of organic matter $\left(C O D_{S}\right)$}

It is noted that there was a significant difference between the treatments subjected to mesophilic and thermophilic temperatures ( $\mathrm{p}<0.05, \mathrm{~F}$ - test), in which the co-digestion at $35^{\circ} \mathrm{C}$ obtained the highest $\mathrm{COD}_{\mathrm{S}}$ removal efficiencies, Figure 2. Similar results were obtained in studies by Xiao, Shi and Ruan (2019), who compared the performance of anaerobic digestion at mesophilic $\left(39^{\circ} \mathrm{C}\right)$ and thermophilic temperatures $\left(55^{\circ} \mathrm{C}\right)$ using leachate from kitchen residues as a substrate, and observed that the anaerobic digestion in the mesophilic range presented better digestive performance, supporting a higher organic loading rate, presenting greater stability, and better $\mathrm{COD}_{\mathrm{S}}$ removal efficiency (98\%) when compared to thermophilic digestion. The authors attributed these results to the fact that the thermophilic anaerobic biomass is more sensitive to the accumulation of VFAs, compared to the mesophilic biomass.

Considering that according to KIM; KIM; YUN (2017), the thermophilic anaerobic digestion process, when compared to the mesophilic, is much more sensitive to load shocks, the addition of inhibiting materials, and variations in temperature, and admitting a maximum variation of $2{ }^{\circ} \mathrm{C}$ per day, the accumulation of VFA may have also been caused by variations in temperature, during co-digestion ( of $\pm 2{ }^{\circ} \mathrm{C}$ ), since during the development of the experiment there were unforeseen power outages in the laboratory.

In this manner, all treatments at $35{ }^{\circ} \mathrm{C}$ obtained $\mathrm{COD}_{\mathrm{S}}$ removals above $50 \%$, in which $\mathrm{T}_{1 \mathrm{M}}, \mathrm{T}_{2 \mathrm{M}}$, and $\mathrm{T}_{3 \mathrm{M}}$ reached maximum removals of 58,53 , and $63 \%$, respectively. Although $\mathrm{T}_{1 \mathrm{M}}$ did not present the highest $\mathrm{COD}_{\mathrm{S}}$ removal, the removal verified is seen as satisfactory, considering the application of $95 \%$ of EAV in the mixture composition of this treatment and the difficulty in the treatment of recalcitrant agro-industrial effluents. Furthermore, although there was no statistically significant difference between treatments in mesophilic temperature ( $p>0.05$, F-test), $\mathrm{T}_{3 \mathrm{M}}$ presented the highest efficiency in organic matter removal. This result is attributed to the lower COD concentration applied to this treatment, a result of the higher percentage of domestic sewage present in this treatment, since the domestic sewage promoted the dilution of the agro-industrial effluent studied, increasing the water content, and also favoring the hydrolysis process, which is the initial stage of the digestion process.

However, it is worth noting that the removal efficiencies verified for all treatments at $35{ }^{\circ} \mathrm{C}$ were considered satisfactory when compared to other works present in the literature, employing the anaerobic co-digestion of agroindustrial and agricultural effluents at mesophilic temperatures. Cremonez et al. (2015) conducted anaerobic co-digestion studies with swine wastewater and vinasse in a UASB reactor at $35{ }^{\circ} \mathrm{C}$ and obtained a total COD removal around $68 \%$. Although this removal was superior to those obtained here, it is highlighted that the present study used the $\mathrm{COD}_{\mathrm{S}}$ as a parameter, not comprising, therefore, the insoluble COD parcel (particulate), which probably will not be stabilized by microorganisms. Náthia-Neves, Forster-Carneiro and Berni (2015), also in anaerobic co-digestion assays with food residues and mesophilic sludge from vinasse treatment, at mesophilic temperature conditions $\left(37^{\circ} \mathrm{C}\right)$, using a system of three sequential reactors operating semi-continuously, obtained $48 \%$ of total COD removal in the methanogenic reactor.

Evaluation and performance of the process: Mass balance in terms of COD and kinetics of the reaction

For both temperatures, the percentage of anaerobic biodegradability of all treatments was above $69 \%$, indicating that the application of co-digestion constitutes a viable and efficient alternative for the removal of organic matter, either at $35^{\circ} \mathrm{C}$ or $55^{\circ} \mathrm{C}$, see Table 3 .

Considering the studies performed by André et al. (2019), which consider the existence of a relevant inorganic fraction and recalcitrant organic fraction in the green acerola processing effluent, the verified results demonstrate that the association of this effluent with domestic sewage contributed to a high biodegradability, since, according to Bertolino, Carvalho and Aquino (2008), the domestic sewage is essentially organic. 
Figure $2-\mathrm{COD}_{\mathrm{S}}$ removal efficiency $(\%)$ at 35 and $55^{\circ} \mathrm{C}$.

Source: The authors.

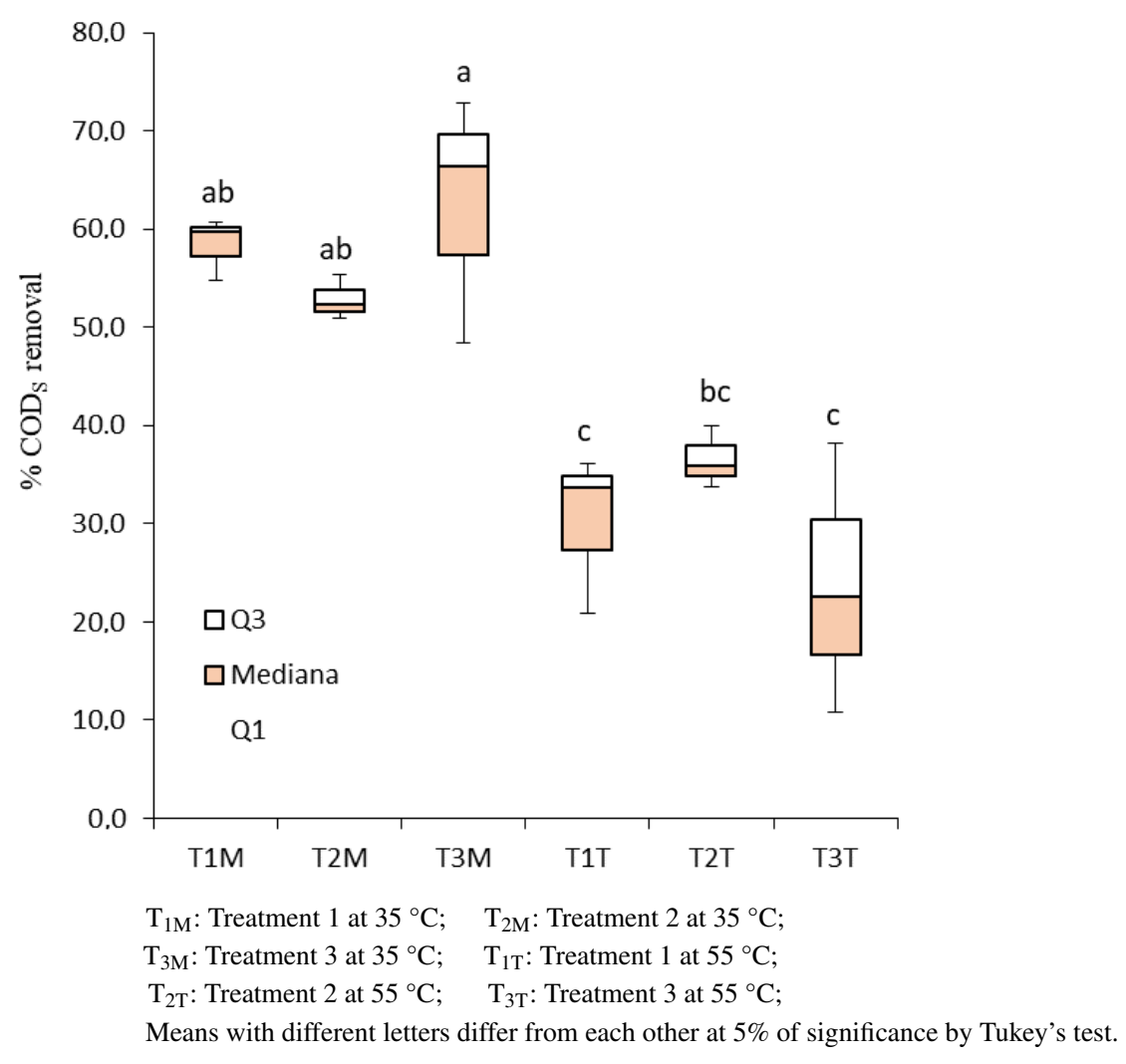

Table 3 - Composition of green acerola processing effluent (EAV) and treated domestic sewage (EDT).

\begin{tabular}{|c|c|c|c|c|c|c|}
\hline Treatments & $\mathbf{T}_{1 \mathrm{M}}$ & $\mathbf{T}_{2 M}$ & $\mathbf{T}_{\mathbf{3 M}}$ & $\mathbf{T}_{\mathbf{1 T}}$ & $\mathbf{T}_{2 \mathbf{T}}$ & $\mathbf{T}_{3 \mathbf{T}}$ \\
\hline$\% \mathrm{BD}$ & $\begin{array}{c}90 \\
\pm 3.7\end{array}$ & $\begin{array}{c}71 \\
\pm 1.8\end{array}$ & $\begin{array}{c}76 \\
\pm 0.2\end{array}$ & $\begin{array}{c}69 \\
\pm 1.2\end{array}$ & $\begin{array}{c}69 \\
\pm 3.1\end{array}$ & $\begin{array}{c}69 \\
\pm 15.0\end{array}$ \\
\hline$\% \mathrm{M}$ & $\begin{array}{l}48 \mathrm{a} \\
\pm 2.6\end{array}$ & $\begin{array}{c}47 \mathrm{a} \\
\pm 5.2\end{array}$ & $\begin{array}{c}51 \mathrm{a} \\
\pm 10.7\end{array}$ & $\begin{array}{l}26 \mathrm{~b} \\
\pm 4.7\end{array}$ & $\begin{array}{l}32 \mathrm{ab} \\
\pm 2.2\end{array}$ & $\begin{array}{c}20 \mathrm{~b} \\
\pm 11.4\end{array}$ \\
\hline $\mathrm{COD}_{\mathrm{VFA}}(\mathrm{g})$ & $\begin{array}{c}15 \\
\pm 1.4\end{array}$ & $\begin{array}{c}11 \\
\pm 1.5\end{array}$ & $\begin{array}{c}8 \\
\pm 1.7\end{array}$ & $\begin{array}{l}22 \mathrm{~b} \\
\pm 1.3\end{array}$ & $\begin{array}{c}18 \\
\pm 0.5\end{array}$ & $\begin{array}{c}14 \\
\pm 3.1\end{array}$ \\
\hline $\mathrm{K}_{\mathrm{d}}\left(\mathrm{d}^{-1}\right)$ & $\begin{array}{c}0.09 \\
\pm 0.001\end{array}$ & $\begin{array}{c}0.10 \\
\pm 0.004\end{array}$ & $\begin{array}{c}0.10 \\
\pm 0.013\end{array}$ & $\begin{array}{c}0.04 \\
\pm 0.002\end{array}$ & $\begin{array}{c}0.06 \\
\pm 0.004\end{array}$ & $\begin{array}{c}0.06 \\
\pm 0.013\end{array}$ \\
\hline \multicolumn{7}{|c|}{ 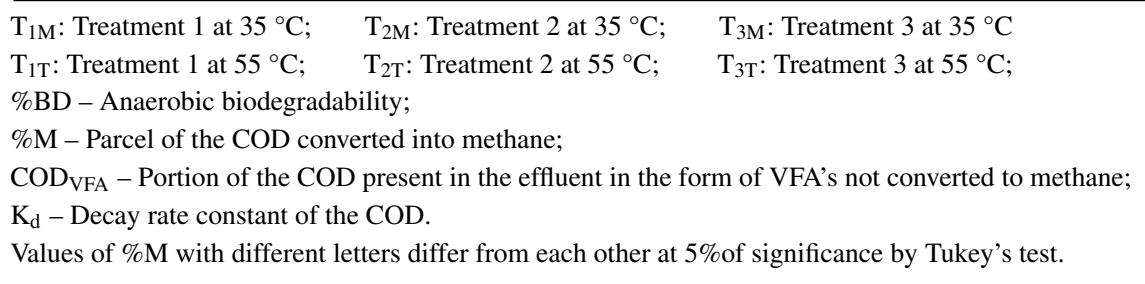 } \\
\hline
\end{tabular}

Source: The authors.

It is observed that among the treatments at $35^{\circ} \mathrm{C}$, $\mathrm{T}_{1 \mathrm{M}}$ - treatment with the highest percentage of agroindustrial effluent - presented the highest percentage of transformed soluble organic matter, that is, \%BD, which indicates that this was the most biodegradable treatment. However, part of this transformed organic matter (biode- graded and not converted into methane) in $\mathrm{T}_{1 \mathrm{M}}$ remained in the reactor flasks in the form of VFA, as the results of the CODVFA demonstrated, Table 3. On the other hand, although $\mathrm{T}_{3 \mathrm{M}}$ has presented a lower \% $\mathrm{BD}$ compared to the $\mathrm{T}_{1 \mathrm{M}}$, it presented higher $\mathrm{COD}_{\mathrm{S}}$ removal, Figure 2, and higher conversion of this into methane (51\%). 
The same could not be observed in the treatments at $55^{\circ} \mathrm{C}$, which presented the same $\% \mathrm{BD}$, probably due to the instabilities observed at this operating temperature, such as greater sensitivity of the thermophilic anaerobic biomass to accumulation of VFA.

When comparing the operating temperatures, it is observed that the highest VFAs accumulations occurred in the treatments at $55^{\circ} \mathrm{C}$. These results relate directly to the removal efficiency of the $\mathrm{COD}_{\mathrm{S}}$ and to the percentage of $\% \mathrm{M}$, in which the treatments with the highest accumulations of VFAs presented the lowest $\mathrm{COD}_{\mathrm{S}}$ removal efficiencies and conversion of this into methane. These results corroborate studies performed by Xiao, Shi and Ruan (2019), in which the thermophilic anaerobic digestion reinforces the toxicity of the VFAs, a fact that implies on the decrease of microbial activity, damaging the aerobic digestion process.

In this manner, the mesophilic treatments $\left(35^{\circ} \mathrm{C}\right)$ also presented the highest percentages of $\% \mathrm{M}$ compared to the thermophilic range, with methanogenic bacteria being the most affected in this process $\left(55^{\circ} \mathrm{C}\right)$.

However, it is worth noting that, in all treatments, there were percentage differences between $\% \mathrm{BD}$ and $\% \mathrm{M}$ above 5\%, a circumstance that according to Elbeshbishy and Nakhla (2012) suggests that there was inhibition of methanogenesis during the stabilization process of the organic matter in all treatments and both temperatures studied. Such a fact is also justified by the COD ${ }_{V F A}$, that is, the highest values occurred for the treatments with the highest percentages of recalcitrant effluent, those with the highest trends toward the acidification or accumulation of VFAs since their chemical composition presents higher percentages of insoluble matters, thus evidencing the positive influence of domestic sewage as a co-substrate.

However, the results verified for the $\mathrm{COD}_{\mathrm{S}}$ removal in the treatments at $35{ }^{\circ} \mathrm{C}$ did not indicate inhibition problems of biodigestion, thus indicating that the microbial communities in these reactor flasks showed to be adapted to environments with high concentrations of COD and VFAs.

As can be seen in Table 3, there was no statistically significant difference ( $\mathrm{p}>0.05$, F-test) among the treatments at $35{ }^{\circ} \mathrm{C}$ with respect to the $\% \mathrm{M}$, however, it is noteworthy that among these treatments $\mathrm{T}_{3 \mathrm{M}}$ presented the highest percentage of methanization $(\% \mathrm{M})$ even being the treatment with the lowest concentration of COD applied (Table 3), besides also presenting the highest percentage of COD effectively removed, Figure 2, and lower mass of COD present in the effluent in the form of VFA, COD $_{\text {VFA }}$, Table 3 . Thus, treated domestic sewage is a potential co-substrate to improve the process of anaerobic digestion in agro-industrial effluents.

The treatments under mesophilic temperature presented the highest $\mathrm{K}_{\mathrm{d}}$ values when compared to the thermophilic temperature range, Table 3. This result relates to the highest values of $\% \mathrm{BD}$ and $\% \mathrm{M}$ observed in these treatments, in which the removal of COD and its conversion into methane occurred more efficiently.

It is worth noting that the mixture composition of the treatments was directly related to the $\mathrm{K}_{\mathrm{d}}$, in which treatments with a higher percentage of domestic sewage, regardless of temperature, presented the highest $\mathrm{K}_{\mathrm{d}}$ values. These results are probably associated to the higher degradability of the organic material present in the domestic sewage, since this - unlike the green acerola processing effluent - is mostly found in the soluble form, and to a lesser extent in particulate form.

Furthermore, considering that according to Metcalf and Eddy (2003), the kinetics of anaerobic degradation is ruled by the slowest stage of effluent conversion (usually the methane formation stage), the lowest values found for the treatments at $55{ }^{\circ} \mathrm{C}$ corroborate with a possible negative interference under methanogenic microorganisms when presenting the lowest $\mathrm{K}_{\mathrm{d}}$ values.

The $K_{d}$ values obtained in all treatments, regardless of the operating temperature, are considered low when compared to the values obtained for domestic wastewaters, $\mathrm{K}_{\mathrm{d}}$ $1.62 \mathrm{~d}^{-1}$ (BRASIL et al., 2007) and $\mathrm{K}_{\mathrm{d}} 1.72 \mathrm{~d}^{-1}$ (CHAGAS et al., 2011), and for slaughterhouse wastewater, $\mathrm{K}_{\mathrm{d}}$ $0.2203 \mathrm{~d}^{-1}$ (LOPES et al., 2015).

\section{Morphological analysis of the microbial biomass}

At the end of the assays, the morphology of the microorganisms present in the biomass of the treatments was observed, presenting the highest $\% \mathrm{M}$ at 35 and $55{ }^{\circ} \mathrm{C}\left(\mathrm{T}_{3 \mathrm{M}}\right.$ and $\mathrm{T}_{2 \mathrm{~T}}$, respectively), shown in Figure 3.

In the biomass of $\mathrm{T}_{3 \mathrm{M}}$, the presence of short bacilli is verified, whose morphology resembles that of methanogenic archaea of the species Methanobrevibacter smithii, Figure 3a), filamentous with flattened ends, like bamboo sticks, resembling Methanosaeta, Figure 3b), and short and long rod-shaped individuals that resemble Methanobacterium, Figure 3c). 
Figure 3 - Micrographs of the biomass samples present in: a)-c): $T_{3 M}$ and d) $T_{2 T}$

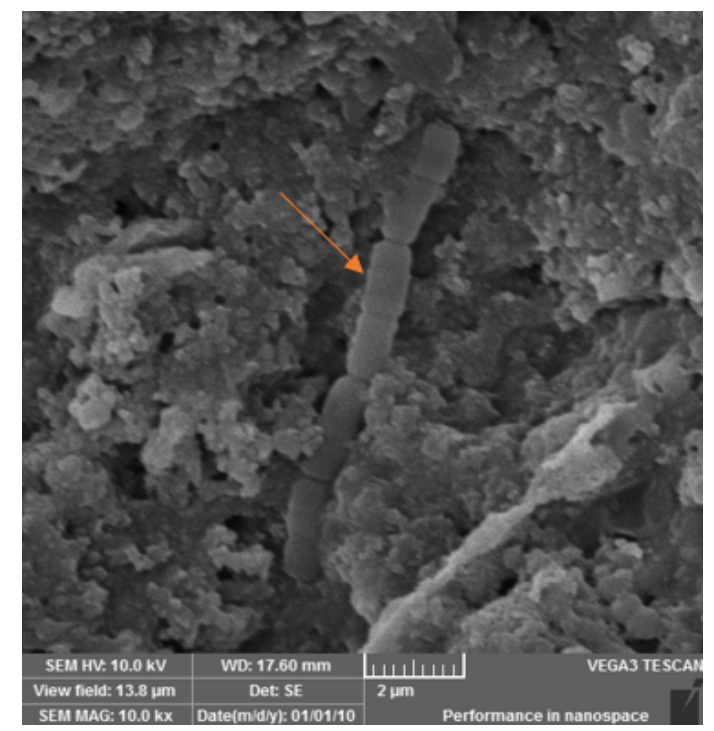

a) Short bacilli similar to Methanobrevibacter smithii $\left(\mathrm{T}_{3 \mathrm{M}}\right)$

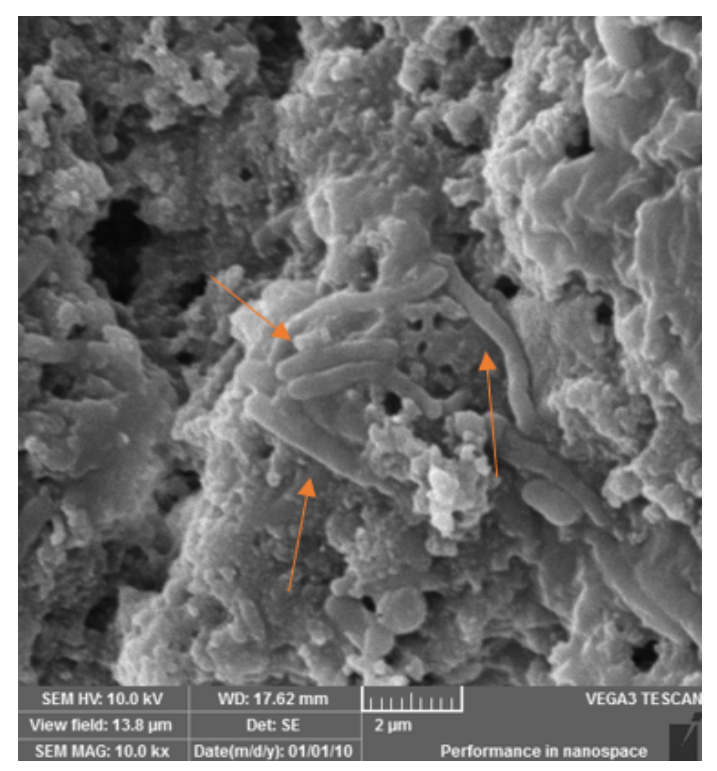

c) Long rod-like rods similar to

Methanobacterium $\left(\mathrm{T}_{3 \mathrm{M}}\right)$;

Source: The authors.

Such morphologies demonstrate a greater biomass structuration in this treatment, evidencing the balanced presence of groups responsible for methanation. In fact, it was the treatment that presented the lowest $\mathrm{COD}_{\mathrm{VFA}}$ mass and the highest methanation percentage, $8 \mathrm{~g}$ and $51 \%$, respectively. The presence of Methanosaeta is associated with low concentrations of volatile fatty acids (VRIEZE $e t$ al., 2012). Methanosaeta is, along with Methanosarcina, the two only acetoclastic genera able to convert acetate into methane, thus explaining the higher methanation percentage found in this treatment. In the biomass of $\mathrm{T}_{2 \mathrm{~T}}$, only similar morphologies to methanogenic archaea of the

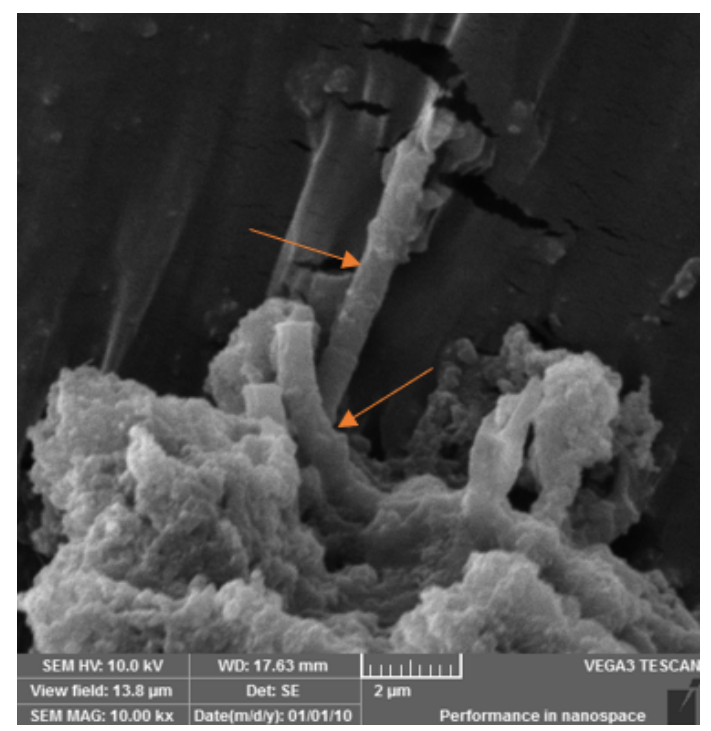

b) Bamboo bud-like filaments similar to Methanosaeta $\left(\mathrm{T}_{3 \mathrm{M}}\right)$;

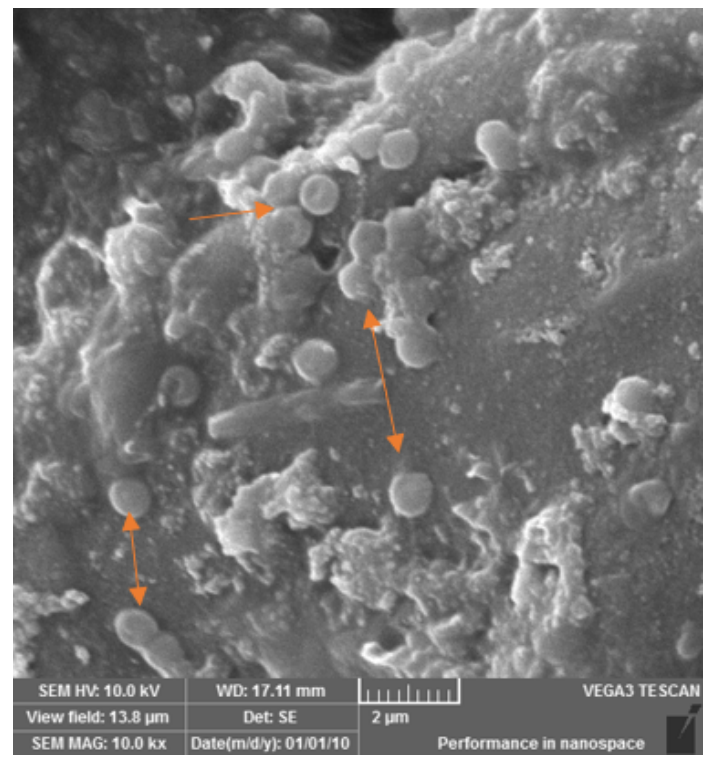

d) Cocci similar to Methanosarcina thermophila $\left(\mathrm{T}_{2 \mathrm{~T}}\right)$;

genus Methanosarcina thermophila are observed, justifying the fact that this is the thermophilic treatment with the highest methanation (32\%), Figure 3d).

The lower microbial diversity found at $55{ }^{\circ} \mathrm{C}$ is also associated with the higher accumulation of VFAs in the treatments subjected to this temperature since some volatile fatty acids, according to Mussati et al., (2005) present a toxic effect at low concentrations on some genera of methanogenic archaea, such as Methanobrevibacter, thus inhibiting their growth and causing the decrease of methane production. 
In spite of the existence of methanogenic archaea at both temperatures, the presence of similar morphologies is not observed, which indicates that this operating parameter of the reactor flasks exerts influence on the microbial communities that act in the process of anaerobic co-digestion, corroborating the studies performed by Zhang et al. (2019), who, when comparing the mesophilic and thermophilic digestion of soybean processing by-products, concluded that the temperature and the organic loading rate are variable and that they change the taxonomic diversity of genera of methanogenic archaea.

\section{Conclusion}

The present study evaluated the effects of temperature on the anaerobic co-digestion of acerola agro-industry effluent and treated domestic sewage. The results showed that co-digestion proved to be an efficient alternative for all treatments, with biodegradability above $69 \%$. Therefore, it is an effective alternative to minimize the recalcitrant effects of this type of effluent.

The mesophilic condition favored the process of anaerobic co-digestion with all treatments, presenting $\mathrm{COD}_{\mathrm{S}}$ removals and its conversion into methane above $50 \%$ and $45 \%$, respectively. Among the treatments at 35 ${ }^{\circ} \mathrm{C}$, the one with the highest percentage of sewage applied presented the highest $\mathrm{COD}_{\mathrm{S}}$ removal efficiency and its conversion into methane (63\% and $51 \%$, respectively). This condition also presented the highest values of $\mathrm{K}_{\mathrm{d}}$.

The biomass of the mesophilic treatments exhibited greater microbial diversity, with the predominance of methanogenic archaea of the genera Methanobrevibacter, Methanosaeta, and Methanobacterium, resulting in better percentages of biodegradation and methanization.

\section{Acknowledgments}

To the Ministry of Education (MEC/Programa de Educação Tutorial (PET) Saneamento Ambiental) for the financial incentive and scholarship maintenance. To the agroindustry Nichirei do Brasil Agrícola Ltda for its partnership and support.

\section{References}

AMANI, T.; NOSRATI, M.; SREEKRISHNAN, T. R. Anaerobic digestion from the viewpoint of microbiological, chemical, and operational aspects a review. Environmental Reviews, Canadian Science Publishing, [London], v. 18, p. 255-278, 2010. DOI: 10.1139/A10-011.

ANDRÉ, A. C. L.; AMORIM, M. C. C.; SILVA, K. C. D.; SILVA, P. T. S. Biochemical potential of methane of wastewater ultrafiltration in the processing of unriped green acerola (Malpighia emarginata). Semina: Ciências Exatas e Tecnológicas. v. 41, n. 2, p. 135-144, 2020. DOI: $10.5433 / 1679-0375.2020 v 41 n 2 p 135$.

ANDRÉ, A. C. L.; SILVA, R. T.; SILVA, K. C. D.; SILVA, P. T. S.; AMORIM, M. C. C. Biodegradabilidade anaeróbia de efluente do processamento da acerola verde. Revista Eletrônica de Gestão e Tecnologias Ambientais, Salvador, v. 7, n. 1, p. 26-36, 2019. DOI: $10.9771 /$ gesta.v7i7.28070.

APHA - AMERICAN PUBLIC-HEALTH ASSOCIATION. Standard methods for the examination of water and wastewater. Washington (DC): [ $\left.\begin{array}{ll}s & . n .\end{array}\right]$, 2012.

ARAÚJO, J. C.; TÉRAN, F. C.; OLIVEIRA, R. A.; NOUR, E. A. A.; MONTENEGRO, A. P.; CAMPOS, J. R.; VAZOLLER, R. F. Comparison of hexamethyldisilazane and critical point drying treatments for SEM analysis of anaerobic biofilms and granular sludge. Journal of Electron Microscopy, v. 52, n. 4, p. 429-433, 2003.

ATANDI, E.; RAHMAN, S. Prospect of anaerobic codigestion of dairy manure: a review. Environmental Technology reviews, Abington, v. 1, n. 1, p. 127-135, 2012. DOI: 10.1080/09593330.2012.698654.

BERTOLINO, S. M.; CARVALHO, C. F.; AQUINO, S. F. Caracterização e biodegradabilidade aeróbia e anaeróbia dos esgotos produzidos em campus universitário. Revista Engenharia Sanitária Ambiental, Rio Claro, v. 13, n. 3, p. 271-277, 2008. DOI: $10.1590 / \mathrm{S} 1413-41522008000300005$. 
BOLZONELLA, D.; PAPA, M.; DA ROS, C; MUTHUKUMAR, L. A.; ROSSO, D. Winery wastewater treatment: a critical overview of advanced biological processes. Journal Critical Reviews in Biotechnology, Boca Raton, v. 39, n. 4, p. 489-507, 2019. DOI: 10.1080/07388551.2019.1573799.

BRASIL, M. S.; MATOS, A. T.; SILVA, C. M.; CECON, P. R.; SOARES, A. A. Modeling of pollution removal in constructed wetlands with horizontal subsurface flow. Agricultural Engineering Research, v. 13, p.48-56, 2007.

CHAGAS, R. C.; MATOS, A. T.; CECON, P. R.; MONACO, P. A. V.; FRANÇA, L. G. F. Cinética de remoção de matéria orgânica em sistemas alagados construídos cultivados com lírio amarelo. Revista Brasileira de Engenharia Agrícola e Ambiental, v. 15, n. 11, 2011.

CHOW, W. L.; CHONG, S.; LIM, J. W.; CHAN, Y.J.; CHONG, M. F.; TIONG, T. J.; CHIN, J. K.; PAN, G. Anaerobic Co-Digestion of Wastewater Sludge: A Review of Potential Co-Substrates and Operating Factors for Improved Methane Yield. Processes, Basel, v. 8, n. 39, 2020. DOI: $10.3390 /$ pr8010039.

CORREIA, G. T.; DEL BIANCHI, V. L. Tratamento biológico de água residuária da produção de farinha de mandioca utilizando reator anaeróbico compartimentado vertical (RACOV). Semina: Ciências Exatas e Tecnológicas, Londrina, v. 29, n. 2, p. 159-166, 2008.

CREMONEZ, P.A.; DE ROSSI, E.; FEROLDI, M.; TELEKEN, J.G.; FEIDEN, A.; DIETER, J. Codigestão de água residual de suinocultura e vinhaça sob diferentes condições térmicas. Revista de Ciências Agrárias, Lisboa, v. 38, n. 1, p. 103-110, 2015.

DE CLERCQ, D.; WEN, Z.; GOTTFRIED, O.; SCHMIDT, F.; FEI, V. A review of global strategies promoting the conversion of food waste to bioenergy via anaerobic digestion. Renewable and Sustainable Energy Reviews, [London], v. 79, p. 204-221, 2017. DOI: $10.1016 /$ j.rser.2017.05.047.

ELBESHBISHY, E.; NAKHLA, G. Batch anaerobic codigestion of proteins and carbohydrates. Bioresource Technology, New York, v. 116, p. 170-178, 2012. DOI: 10.1016/j.biortech.2012.04.052.
ESPOSITO, G.; FRUNZO, L.; GIORDANO, A.; LIOTTA, F.; PANICO, A.; PIROZZI, F. Anaerobic co-digestion of organic wastes. Reviews Environmental Science and Bio/Technology, [Dordrecht], v. 11, p. 325-341, 2012. DOI: $10.1007 /$ s11157-012-9277-8.

FERREIRA, D. F. Sisvar: a computer statistical analysis system. Ciência e Agrotecnologia, Lavras, v. 35, n. 6, p. 1039-1042, 2011.

FLORÊNCIO, L. The fate of metanol in anaerobic bioreactors. 1994. Thesis (Phd) - Wageningen Agricultural University, Wageningen, 1994.

HAGOS, K.; ZONG, J.; LI, D.; LIU, C.; LU, X. Anaerobic co-digestion process for biogas production: Progress, challenges and perspectives. Renewable and Sustainable Energy Reviews, [London], v. 76, p. 1485-1496, 2017. DOI: $10.1016 /$ j.rser.2016.11.184.

HOLLIGER, C.; ALVES, M.; ANDRADE, D.; ANGELIDAKI, I.; ASTALS, S.; BAIER, U.; BOUGRIER, C., BUFFIERE, P., CARBALlA, M., DE WILDE, V., EBERTSEDER, F.; FERNANDEZ, B.; FICARA, E.; FOTIDIS, I.; FRIGON, J.-C.; DE LACLOS, H.F.; GHASIMI, D.S.M.; HACK, G.; HARTEL, M.; HEERENKLAGE, J.; HORVATH, I.S.; JENICEK, P.; KOCH, K.; KRAUTWALD, J.; LIZASOAIN， J.; LIU， J.; MOSBERGER, L.; NISTOR, M.; OECHSNER, H.; OLIVEIRA, J.V.; PATERSON, M.; PAUSS, A.; POMMIER, S.; PORQUEDDU, I.; RAPOSO, F.; RIBEIRO, T.; RUSCH PFUND, F.; STROMBERG, S.; TORRIJOS, M.; VAN EEKERT, M.; VAN LIER, J.; WEDWITSCHKA, H.; WIERINCK, I. Towards a standardization of biomethane potential tests. Water Science Technology. Colchester, v. 74, n. 11, p. 1-9, 2016. DOI: $10.2166 /$ wst.2016.336

KIM, M.; KIM, D.; YUN, Y. Effect of operation temperature on anaerobic digestion of food waste: performance and microbial analysis. Fuel, London, v. 209, p. 598-605, 2017. DOI: 10.1016/j.fuel.2017.08.033.

LOPES, C. L.; GOMES, S. D.; LIMA-MODEL, A. N.; KREUTZ, C.; PASSIG, F. H. Cinética da remoção de matéria orgânica de água residuária de abatedouro de aves em reator compartimentado anaeróbio-aeróbio. In: IV Simpósio Internacional sobre Gerenciamento de Resíduos Agropecuários e Agroindustriais. Rio de Janeiro, Brasil, 2015. 
MALEGORI, C.; MARQUES, E. J. N.; FREITAS, S. T.; PIMENTEL, M. F.; PASQUINI, C.; CASIRAGHI, E. Comparing the analytical performances of microNIR and FTONIR spectrometers in the evaluation of acerola fruit quality, using PLS and SVM regression algorithms. Talanta, Oxford, v. 165, p. 112-116, 2017. DOI: $10.1016 /$ j.talanta.2016.12.035.

METCALF, L.; EDDY, H. P. Wastewater engineering: treatment, disposal and reuse. 4. ed. New York: McGrawHillBook, 2003.

MONTEFUSCO, N. E. G.; ANDRÉ, A. C. L.; BARBOSA, P. S.; MATOS, R. S.; AMORIM, M. C. C. Biodegradabilidade anaeróbia de efluentes da agroindústria aceroleira. In: ZUFFO, A. M. (org.). Engenharia sanitária e ambiental: tecnologias para a sustentabilidade 2. Ponta Grossa: Atena Editora, 2019. v. 2, p. 182193. Ebook. ISBN 978-85-7247-250-0.

MUSSATI, M.; THOMPSON, C.; FUENTES, M.; AGUIRRE, P.; SCENNA, N. Characteristics of a methanogenic biofilm on sand particles in a fluidized bed reactor. Latin American Applied Research, v. 35, n. 4, p. 265-272, 2005.

NÁTHIA-NEVES, G.; NEVES, T. A.; BERNI, M.; DRAGONE, G.; MUSSATTO, S. I.; FORSTERCARNEIRO, T. Star-up phase of a two-stage anaerobic co-digestion process: hydrogen and methane production from food waste and vinasse from ethanol industry. Biofuel Research Journal v. 18, p. 813-820, 2018. DOI: $10.18331 / \mathrm{BRJ} 2018.5 .2 .5$.

NIKOLAEVA, S.; SÁNCHEZ, E.; BORJA, R.; RAPOSO, F.; COLMENAREJO, M. F.; MONTALVO, S.; JIMÉNEZ-RODRÍGUEZ. Kinetics of anaerobic degradation of screened dairy manure by upflow fixed bed digesters: Effect of natural zeolite addition. Journal of Environmental Science and Health, Part A: Toxic/Hazardous Substances and Environmental Engineering, 44:2, 146154, 2009. DOI: 10.1080/10934520802539715.

PENHA, E. M.; BRAGA, N. A. S.; MATTA, V. M.; CABRAL, L. M. C.; MODESTA, R. C. D.; FREITAS, S. C. Utilização do retentado da ultrafiltração do suco de acerola na elaboração de licor. B. CEPPA, [S. l.], v. 19, n. 2, p. 267-276, 2001.
PUKASIEWICZ, S. R. M.; GOMES, S. D.; DE OLIVEIRA, J. G. B.; BARANA, A. C. Upflow anaerobic filter for pet food wastewater treatment. Semina: Ciências Exatas e Tecnológicas, Londrina, v. 38, n. 1, p. 55-62, 2017. DOI: 10.5433/1679-0375.2017v38n1p55.

RITMANN, B. E.; MCCARTY, P. L. Environmental biotechnology: principies and applications. New York: Mc Graw Hill Education, 2001.

SHEN, R.; ZHAO, L.; LU, J.; WATSON, J.; SI, B.; CHEN, X.; MENG, H.; YAO, Z.; FENG, J.; LIU, J. Treatment of recalcitrant wastewater and hydrogen production via microbial electrolysis cells. International Journal Agricultural and Biological Engineering, Beijing, v. 12, n. 5, p. 179-188, 2019. DOI: $10.25165 /$ j.ijabe.20191205.5061.

SIDDIQUE, M. N. I.; WAHID, Z. A. Achievements and perspectives of anaerobic co-digestion: a review. Journal of Cleaner Production, Oxford, v. 194, p. 359-371, 2018. DOI: $10.1016 / \mathrm{j} . j c l e p r o .2018 .05 .155$.

STOFFEL, F.; MOREIRA, A. S. S. Aplicação de micro e ultrafiltração no processamento de sucos de fruta: revisão. B. CEPPA, [S. l.], v. 31, n. 2, p. 321-336, 2013. DOI: $10.5380 /$ cep.v31i2.34855.

VRIEZE, J.; HENNEBEL, T.; BOON, N.; VERSTRAETE, W. Methanosarcina: The rediscovered methanogen for heavy duty biomethanation. Bioresource Technology, New York, v. 112, p. 1-9, 2012. DOI: 10.1016/j.biortech.2012.02.079.

WIJAYA, A. S.; JARIYABOON, R.; REUNGSANG, A.; KONGJAN, P. Biochemical methane potential (BMP) of cattle manure, chicken manure, rice straw, and hornwort in mesophilic mono-digestion. International Journal of Integrated Engineering, [Malaysia], v. 12, n. 3, p. 1-8, 2020. DOI: 10.30880/ijie.2020.12.03.001.

XIAO, X.; SHI, W.; RUAN, W. Performance and microbial community structure of anaerobic membrane bioreactor for lipids-rich kitchen waste alurry treatment: mesophilic and thermophilic processes. Processes, Basel, v. 7, p. 879, 2019. DOI: $10.3390 /$ pr7120879. 
XU, N.; LIU, S.; XIN, F.; ZHOU, J.; JIA, H.; XU, J.; JIANG, M.; DONG, W. Biomethane production from lignocellulose: biomass recalcitrance and its impacts on anaerobic digestion. Frontiers in Bioengineering and Biotechnology, Lausanne, v. 7, article 191, 2019. DOI: $10.3389 /$ fbioe.2019.00191.

ZHANG, C.; XIAO, G.; PENG, L.; SU, H.; TAN, T. The anaerobic co-digestion of food waste and cattle manure. Bioresource Technology, New York, n. 129, p. 170-176, 2013. DOI: 10.1016/j.biortech.2012.10.138.
ZHANG, L.; LOH, K.; SARVANANTHARAJAH, S.; TONG, Y. W.; WANG, C.; DAI, Y. Mesophilic and thermophilic anaerobic digestion of soybean curd residue for methane production: characterizing bacterial and methanogen communities and their correlations with organic loading rate and operating temperature. Bioresource Technology, New York, v. 288, 2019. DOI: 10.1016/j.biortech.2019.121597. 